Jahrbuch für Geschichte Lateinamerikas

Anuario de Historia de América Latina

54 | 2017 | 258-280

\title{
Fabian Fechner
}

Fernuniversität in Hagen

Knowledge Knots on the Spot

Colonial Archives through the Looking Glass of the Archival Turn - the Cases of Caracas and Buenos Aires
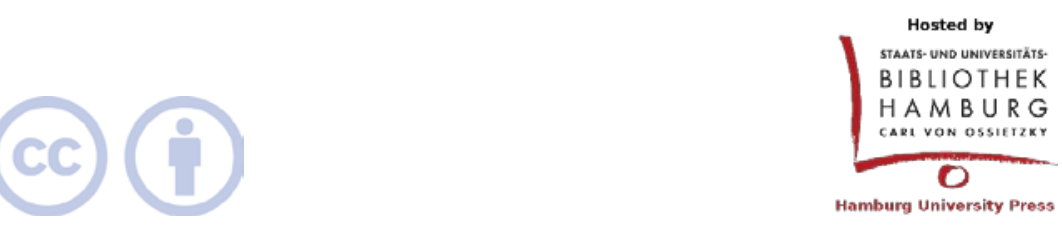

Except where otherwise noted, this article is licensed under a Creative Commons Attribution 4.0 International license (CC BY 4.0)

https://doi.org/10.15460/jbla.54.26 


\title{
Knowledge Knots on the Spot Colonial Archives through the Looking Glass of the Archival Turn - the Cases of Caracas and Buenos Aires
}

\author{
Fabian Fechner
}

Resumen. - La historia global de los saberes desarrollada durante los últimos años se ha focalizado en analizar las condiciones de circulación de conocimientos desde una perspectiva que ha privilegiado el análisis de archivos ubicados en las metrópolis europeas. Sin embargo, hasta ahora se ha estudiado muy poco el tema de cómo archivos, librerías y otros repositorios organizaron y estructuraron saberes; cómo ellos mismos conectaron eventos desconectados entre sí y cómo desarrollaron técnicas de archivamiento en un contexto colonial. Sabemos cómo fueron organizados algunos archivos en metrópolis europeas, pero ignoramos los vínculos entre esos archivos y los archivos ubicados en territorios coloniales. El presente artículo analiza ese costado del proceso. Como casos de estudio se toman el archivo de los franciscanos en Caracas y el archivo jesuítico en Buenos Aires, ambos organizados a mediados del siglo XVIII. Los procesos de archivística revelan las categorías de clasificación y hábitos archivísticos en ultramar. A partir de los inventarios, herramientas clave en la organización de los archivos, podemos entender mejor cómo se crearon conocimientos nuevos e incluso obtener elementos para comprender cómo fue concebido el gobierno político local.

Palabras clave: historia global de los saberes; inventorios; gobierno local; prácticas archivísticas.

Abstract. - The global history of knowledge which has developed in recent years is focused on what we know and how we know it. The analysis of global knowledge transfer not only depends on individuals and institutions that made the circulation of information possible, but also on the way documents were intentionally stored and organized. However, the question of how archives, libraries, and other repositories reorganized knowledge, connected disconnected events, and developed techniques of record keeping in a colonial situation has

Jahrbuch für Geschichte Lateinamerikas | Anuario de Historia de América Latina

$54 \mid 2017$

Fabian Fechner, Colonial Archives 
hardly been answered. European central archives are the better known side of information and communication processes, but the aspect of interconnectedness and mutuality in these processes is usually neglected. The main purpose of this paper is to explore the overseas part of the colonial archive, not the European center. As a case study, two Latin American local archives are chosen, the Franciscan Archive in Caracas and the Jesuit Archive in Buenos Aires. The archiving processes in both repositories clarify specific colonial archival genres and archival habits in oversea territories. With exemplary archive inventories as essential organizational tools and instruments for safekeeping we can develop a better understanding of how knowledge was created and how local governance was conceptualized.

Keywords: Global History of Knowledge; Inventories; Local Governance; Archival Practices.

\section{Colonial Archives in the Archival Turn}

Some of the core suggestions of recent archival historiography were discussed under the catchy term "archival turn." This gradual methodological shift can be described as a "move from archive-assource to archive-as-subject" 1 that questions the "obviousness" of the archive. ${ }^{2}$ In a nutshell, the archive is no longer seen as a storehouse of objective truths. $^{3}$

\footnotetext{
${ }^{1}$ Ann Laura Stoler, Along the Archival Grain. Epistemic Anxieties and Colonial Common Sense. Princeton: Princeton University Press, 2008, p. 44. I wish to thank Horst Pietschmann, Oonagh Hayes, Marc-André Grebe, Ybeth Arias Cuba, and Agnes Gehbald for their helpful comments and advice.

${ }^{2}$ For a synthetic discussion of the term "archival turn” see Markus Friedrich, Die Geburt des Archivs. Eine Wissensgeschichte, Munich: Oldenbourg, 2013, pp. 21-23; Stoler, Archival Grain, p. 23; Alexandra Walsham, “The Social History of the Archive. Record-Keeping in Early Modern Europe”: Past \& Present, 230 (2016), Suppl. 11 ("The Social History of the Archive: Record-Keeping in Early Modern Europe"), pp. 948.

${ }^{3}$ Natalie Zemon Davis, Fiction in the Archives. Pardon Tales and Their Tellers in 16th Century France, Stanford: Stanford University Press, 1987; Arlette Farge, Le goût de l'archive, Paris: Le Seuil, 1989; Wolfgang Ernst, Das Rumoren der Archive. Ordnung aus Unordnung, Berlin: Merve Verlag, 2002; Eric Ketelaar, "Records Out and Archives In. Early Modern Cities as Creators of Records and as Communities of Archives": Archival Science, 10 (2010), pp. 201-210. For further developments in historiography see Wilfried Reininghaus, "Archivgeschichte. Umrisse einer untergründigen Subdisziplin”: Der Archivar, 61 (2008), pp. 352-360; Annika Wellmann, "Theorie der Archive - Archive der Macht. Aktuelle Tendenzen der Archivgeschichte”: Neue Politische Literatur, 57 (2012), pp. 385-401; Dietmar Schenk,
} 
Two works are commonly mentioned to explain the recent awakening of interest for archives in cultural history, ${ }^{4}$ but ironically at the same time, they blurred the concept of the archive in a certain way: In studies following Foucault's "Archaeology of Knowledge" and Derrida's "Archive Fever," the term "archive" was not understood as a specific "whole of the writings that were permanently preserved in a determined place, ${ }^{5}$ but as a metaphor. ${ }^{6}$

As has been pointed out on several occasions, the archival turn has had a wider arc than Derrida. ${ }^{7}$ It is not as new as it is supposed to be, and some scholars argue that it can be seen simply as an elaborate form of source critique. ${ }^{8}$ Nevertheless, there came some essential changes with the "archival turn," as Dietmar Schenk highlights. Source critique normally analyzes only one or a few documents at once to estimate the value of sources. After the archival turn and through the analysis of an archive's "power," "an archive complex as a whole is discussed, and this [complex] is understood as an entity which limits and defines

"Aufheben, was nicht vergessen werden darf”. Archive vom alten Europa bis zur digitalen Welt, Stuttgart: Steiner, 2013.

${ }^{4}$ Jacques Derrida, Archive Fever. A Freudian Impression, Chicago 1995; Michel Foucault, The Archaeology of Knowledge, London / New York: Routledge, 2002 (1969).

${ }^{5}$ In Brenneke's seminal handbook, archives are defined as "the whole of the writings and other documents that were accumulated by physical or juridical persons by reason of their practical or juridical activity, and that, as documentary sources and evidence of the past, are destined to permanent preservation in a determined place.” Adolf Brenneke, Archivkunde. Ein Beitrag zur Theorie und Geschichte des europäischen Archivwesens, bearb. nach Vorlesungsnachschriften und Nachlaßpapieren und ergänzt von Wolfgang Leesch, Leipzig: Koehler \& Amelang, 1953, p. 97; English translation modified after Luciana Duranti, "Archives as a Place”: Archives \& Social Studies: A Journal of Interdisciplinary Research, 1 (2007) (1996), pp. 456-457.

${ }^{6}$ As a metaphor to describe knowledge transfer, the term "archive" is used for example in Deborah Thomas, "Caribbean Studies, Archive Building, and the Problem of Violence”: Small Axe, 17 (2016), pp. 27-42; Diana Taylor, The Archive and the Repertoire. Performing Cultural Memory in the Americas, Durham / London: Duke University Press, 2003.

${ }^{7}$ Dietmar Schenk: "'Archivmacht' und geschichtliche Wahrheit”: Rainer Hering / Dietmar Schenk (eds.), Wie mächtig sind Archive? Perspektiven der Geschichtswissenschaft, Hamburg: Hamburg University Press, 2013, pp. 21-43, here p. 37 (for example Brenneke’s concept “Archivgestaltungstypen”); Stoler, Archival Grain, p. 44.

${ }^{8}$ For further examples see Schenk, “Archivmacht”. The current state of the art of elaborate source criticism can be found in Raul Hilberg, Die Quellen des Holocaust. Entschlüsseln und Interpretieren, Frankfurt am Main: S. Fischer Verlag, 2009 (2003); Adam Jones, Zur Quellenproblematik der Geschichte Westafrikas 1450-1900, Stuttgart: Steiner, 1990. 
historic knowledge from the beginning." ${ }^{9}$ Finally, the distance between professional archivists and historians is shrinking, since "the scope has shifted from the institution to the information generating and structuring processes” ${ }^{10}$ in an archive. Thus, two research interests traditionally quite far apart are beginning to open a rich mutual exchange.

When we assume that "the long-term availability of many types of documents has become a key aspect of European civilization,"11 one may wonder if, when, and how the European concept of archive spread in overseas territories, whether it was modified or whether it was combined with indigenous ways of preserving documents. During the times of European domination, these archives may be called "colonial" in the broadest sense, referring to municipal archives and regional archives, and not only restricted to secular authorities, but including ecclesiastical entities like dioceses and religious orders. All of these institutions were directly linked to European administrative centers, and especially in peripheral regions and at the beginning of the European expansion, ecclesiastical authorities could exercise "quasi-state" functions. ${ }^{12}$

Thomas Richards was among the first scholars who drew academic attention to the "archive" as a keyword in a colonial or imperial context. In his well-known study about the intersections between literature and science in late-Victorian and Edwardian fiction, he questions the "unity" of the British Empire around 1900 and suggests instead a kind of "collective improvisation." ${ }^{13}$ In his words, the imperial archive "appears as a prototype for a global system of domination through circulation, an apparatus for controlling territory by producing, distributing and consuming information about it." ${ }^{14}$ With

\footnotetext{
${ }^{9}$ Schenk, “Archivmacht”, p. 36.

${ }^{10}$ Charles Jeurgens, "Information on the Move. Colonial Archives. Pillars of Past Global Information Exchange”: idem / Ton Kappelhof / Michael Karabinos (eds.), Colonial Legacy in South East Asia. The Dutch Archives, Den Haag: Stichting Archiefpublicaties, 2012, pp. 45-65, here p. 51.

${ }^{11}$ Markus Friedrich, "Introduction. New Perspectives for the History of Archives": Arndt Brendecke (ed.), Praktiken der Frühen Neuzeit. Akteure - Handlungen Artefakte, Cologne / Weimar / Vienna: Böhlau, 2015, pp. 468-472, here p. 469.

12 Pedro Borges (ed.), Historia de la Iglesia en Hispanoamérica y Filipinas (siglos XV-XIX), Madrid: Biblioteca de Autores Cristianos, 1992 (2 vols.).

13 Thomas Richards, The Imperial Archive. Knowledge and the Fantasy of Empire, London / New York: Verso, 1993, p. 3; as an overview to the issue "Colonialism and the Archive" see Marlene Manoff, "Theories of the Archive from Across the Disciplines”: Libraries and the Academy, 4 (2004), pp. 9-25, here pp. 15-17.

${ }^{14}$ Richards, The Imperial Archive, p. 17.
} 
this definition, Richards would share the opinion with those who see a centralized archive as the origin of an imperial gaze. But surprisingly, he does not understand the "archive" as a determined place. According to him, it

"was not a building, nor even a collection of texts, but the collectively imagined junction of all that was known or knowable, a fantastic representation of an epistemological master pattern, a virtual focal point for the heterogeneous local knowledges of metropole and empire." 15

Richards' definition of the archive was not very specific. However, through the key term "imperial archive," questions of the distribution and storage of knowledge and documents entered the agenda of historians engaged with colonial matters. Christopher Bayly presented his monograph about "Empire and Information” in India (1780-1870) as another crucial study for the sharpening of questions concerning archival history. With concepts like "economy of knowledge" and "information order" 16 he sought to fill the gap between social history and intellectual history. By analyzing new means of knowing and disseminating information and by regarding earlier traditions of the presentation of knowledge, he made the movement of knowledge within Indian society visible. Besides the Indian case, the colonial Dutch archives is a better known field. Especially Ann Laura Stoler's pioneering study ${ }^{17}$ and the works by Charles Jeurgens helped to understand the importance of archival structures for colonial history. ${ }^{18}$

\footnotetext{
${ }^{15}$ Richards, The Imperial Archive, p. 11. The main purpose of the imperial archive was "the construction of a positive and comprehensive knowledge of the world" ( $p$. 145)

${ }^{16}$ Christopher A. Bayly, Empire and Information. Intelligence Gathering and Social Communication in India, 1780-1870, Cambridge: Cambridge University Press, 1996, pp. 4-5: "What we have called the information order should not be seen as a 'thing,' any more than a state or an economy is a thing; it is a heuristic device, or a field of investigation, which can be used to probe the organisation, values and limitations of past societies. It is not separate from the world of power or economic exploitation, but stands both prior to it and dependent on it. It can be considered to have a degree of autonomy from politics or economic structure. Thus some powers, or powerful groups, with finite economic resources and little brute force - the Republic of Venice in the eighteenth century or the House of Rothschild in the nineteenth, for instance - have had exceptionally well-organised and flexible information systems which allowed them to make their limited caches of power and resources work harder. Likewise, societies at similar levels of economic development, when judged by per capita income, had different styles of information order which shaped their capacity to change internally or resist external pressures."

${ }^{17}$ Stoler, Archival Grain, p. 20: "This book is about such a colonial order of things as seen through the record of archival productions. I ask what insights into the social imaginaries of colonial rule might be gained from attending not only to colonialism's
} 


\section{More than "Center and Periphery" - Archival Critique in the Latin American Case}

Compared with the Dutch and British empires, the Spanish archival structure in the territories oversea is scarcely explored. For the case of Latin America, written culture in general within a colonial situation was recently treated in two monographs concerning the Archive of Simancas. Brendecke analyzed the practices of knowledge production during the reign of Philip II with a special emphasis on the "tangle of relations and possibilities of communication" between local authorities in Spanish America and the Council of the Indies, while Grebe focused on the (only apparently "central") archive in the context of Habsburg governance practices. ${ }^{19}$ Also, only a few studies focus directly on the early modern Latin American side of information management within the Spanish empire. Several recent studies about notarial archives in Quito, Peru, and Guatemala emphasize peculiarities of document types and record keeping for the Spanish colonial setting, ${ }^{20}$ while the archival form and content of the colonial "cabildo" was focused especially on

archival content, but to the principles and practices of governance lodged in particular archival forms. By 'archival form' I allude to several things: prose style, repetitive refrain, the arts of persuasion, affective strains that shape 'rational' response, categories of confidentiality and classification, and not least, genres of documentation."

18 Charles Jeurgens, "Networks of Information. The Dutch East Indies": Catia Antunes / Jos Gommans (eds.), Exploring the Dutch Empire. Agents, Networks and Institutions, 1600-2000, London / New York / New Delhi / Sydney: Bloomsbury, 2015, pp. 95-130, here p. 99: "The archive may have formed the intersection of knowledge about the colonial world, but the question remained to what extent the information was an accurate and reliable representation of colonial reality. The lines between knowledge, fantasy and wishful thinking were easily blurred. The officials in the homeland created their own paper colony [...].”

19 Arndt Brendecke, Imperium und Empirie. Funktionen des Wissens in der spanischen Kolonialherrschaft, Cologne / Weimar / Vienna: Böhlau, 2009, p. 20; MarcAndré Grebe, Akten, Archive, Absolutismus? Das Kronarchiv von Simancas im Herrschaftsgefüge der spanischen Habsburger (1540-1598), Frankfurt am Main: Vervuert, 2012.

${ }^{20}$ Kathryn Burns, Into the Archive. Writing and Power in Colonial Peru, Durham / London: Duke University Press, 2010; Tamar Herzog, Mediación, archivos y ejercicio. Los escribanos de Quito (siglo XVII), Frankfurt am Main: Vittorio Klostermann, 1996; Kathryn Burns: "Notaries, Truth, and Consequences": The American Historical Review, 110: 2 (2005), pp. 43-68; Sylvia Sellers García, Distance and Documents at the Spanish Empire's Periphery, Stanford: Stanford University Press, 2014. Inspired by these studies Fabien Montcher, "Archives and Empire. Scholarly Archival Practices. Royal Historiographers and Historical Writing across the Iberian Empire (Late 16th and Early 17th Century)”: Storia della Storiografia. Rivista internazionale, 68: 2 (2015), (Issue “Archives and the Writing of History”), pp. 21-35. 
continuities with medieval Spanish archive structures. ${ }^{21}$ All these studies show that historicizing the archive allows us to read quite scattered documentation with fresh eyes. Thus, knowledge storage becomes very concrete, and retrospective ideas about omniscient, centralized archives can rather be understood as mere speculations.

Beyond state archives and notarial archives, only a few studies deal with the historical order of ecclesiastical archives, especially from the missionary orders. Among them, Francisco Morales describes the various inventories of the Franciscan "Biblioteca y Archivo de la Provincia del Santo Evangelio de México," preserved for the years 1682, 1705, 1738, 1755, and 1768. This rich documentation is exclusively used to stress the historical importance of one archivist, Fray Francisco Antonio de la Rosa Figueroa (1698-1778) and to foster the development of archives nowadays. In the case of Estela Restrepo Zea's concise article about the Jesuit archives in Santa Fe (Nueva Granada) before the expulsion the preserved inventories are only mentioned, and the research interest focuses more on the Jesuit legislation concerning provincial archives. ${ }^{22}$

21 Alfonso Rubio Hernández, "El archivo del cabildo colonial. Antecedentes históricos”: Historia y espacio, 27 (2006), pp. 1-19; Constantino Bayle, Los cabildos seculares en la América española, Madrid: Sapientia 1952, pp. 341-361; María del Carmen Cayetano Martín, "Archivos municipales en América y España (s. XVXVIII)”: Boletín Anabad, 29 (1989), pp. 3-14. Recently a contemporary focus on Latin American archives had been developed, for example in Kirsten Weld, Paper Cadavers. The Archives of Dictatorship in Guatemala, Durham / London: Duke University Press, 2014.

${ }^{22}$ Francisco Morales, "Los archivos franciscanos de México vistos a través de un franciscano del siglo XVIII. Fray Francisco Antonio de la Rosa Figueroa”: Julio Bunader / Celina A. Lértora Mendoza (eds.), II Simposio sobre Bibliotecas y Archivos del área franciscana en América, España y Portugal. Un aporte a la historia de la cultura de los siglos XVII-XX, Buenos Aires, 26-28 de Agosto de 2004, Buenos Aires: Castañeda 2004, pp. 471-488; for the broader context of the Franciscan archives in Mexico see Lino Gómez Canedo, Archivos Franciscanos en México, México City: Instituto de Investigaciones Bibliográficas, UNAM, 1975. Estela Restrepo Zea, "La formación de la memoria. El archivo de la Compañía de Jesús 1767”: Anuario Colombiano de Historia Social y de la Cultura, 24 (1997), pp. 79-100. About papal legislation concerning ecclesiastical archives see Pedro Rubio Merino, Archivística Eclesiástica. Nociones Básicas, Bogotá: Consejo Episcopal Latinoamericano, 1998. 


\section{An Archive as "alma de este venerable cuerpo" - the Franciscans in Caracas}

The provincial archive of the Franciscans in Caracas was the central archive of the "Provincia de Santa Cruz," located in the Convento máximo de la Inmaculada Concepción de Nuestra Señora. Although this province was the first of the Franciscan friars in the New World ${ }^{23}$ and despite the assumption that provincial headquarters of religious orders required distinct archives, ${ }^{24}$ in the Franciscan case in what today is Venezuela, a structured archive can be traced back only to the late $18^{\text {th }}$ century. The main documentary evidence is a detailed inventory from 1789. Compared to worse documented local archives in Latin America, this example is quite significant from an archival point of view. ${ }^{25}$ Three characteristics of this inventory allow the reconstruction of the inner dynamics of the archive: an elaborate foreword, the continuous mention of the new archivist within the document and hints that allow the understanding of the development of the archive.

The foreword contains a copy of a decision ("auto," "acuerdo") made by the council of the province on May $19^{\text {th }}, 1788$. The copy was certified on July $27^{\text {th }}, 1789$ by Fray Juan Antonio Ravelo, secretary of the province council ("Venerable Difinitorio"). It reveals the precarious state of the provincial archive, because it had been divided into a regular one in the convent in Caracas and a smaller one, which was directly under the personal control of the Provincial. He even used to carry these documents with him as a kind of "portable archive" ("archivo portátil"). Aside from this division and some unclear responsibilities, this archive was not permanently attended. Thus, some crucial documents got lost in the course of the years. The foreword mentions the loss of "algunos instrumentos" and of the official documents with the decisions of the province council ("libros

${ }^{23}$ Lino Gómez Canedo, Los archivos de la historia de América. Período colonial español, México City: Instituto Panamericano de Geografía e Historia, 1961; about Franciscan administration see idem, "Un capítulo de historia institucional. La Organización Franciscana en América”: Montalbán, 1 (1972), pp. 7-32.

${ }^{24}$ Markus Friedrich, "Archives as Networks. The Geography of Record-Keeping in the Society of Jesus”: Archival Science, 10 (2010), pp. 285-298, here p. 287, note 1.

${ }^{25}$ Catálogo del Archivo de la Provincia de Santa Cruz. Año 1789. Archivo Arquidiocesano de Caracas, Fondo Franciscano, legajo $1^{\circ}, \mathrm{N}^{\circ} 1$. Published in Lino Gómez Canedo (ed.), La Provincia franciscana de Santa Cruz de Caracas. Cuerpo de documentos para su historia (1513-1837), Caracas: Biblioteca de la Academia Nacional de la Historia, 1974, vol. 1, pp. 265-343. 
difinitoriales") from the very beginnings of the province in 1505/1513 until 1618. ${ }^{26}$

These severe shortcomings of the archive justified fundamental changes in the management and the administrative structure. First of all, a full archivist was nominated, Fray Manuel de Jesús Nazareno Zidardia. He received one of the two keys of the archive; the second one was given to the "Padres Guardianes." Whenever the Provincial or the province council wanted to consult the documents, the archivist had to come personally and hand them over. Surprisingly, in a certain way even the Provincial himself did not find enough credibility to be entrusted with direct access. Probably, some losses may have occurred in his "portable archive." In this context, the documents were seen as a cornerstone of the Franciscan province, as the "soul of this venerable body" ("alma de este venerable cuerpo"). Due to his advanced age, Brother Zidardia did not have to manage the archive alone. Fray Esteban de San Joaquín Irigoyen was named as a helper in the rank of a writer ("escribiente"). ${ }^{27}$ However, working as a writer did not mean being limited to mere mechanical copying processes. Furthermore, this job included juridical responsibilities because Irigoyen had to be trained in the rules of the province, so he was able to tell his brothers when they transgressed the rules. ${ }^{28}$ For these duties, Irigoyen was not obliged to be present at any of the gatherings and rites of the community, and the prelates were not able to force him to do so. ${ }^{29}$

During the following 14 months, until July $27^{\text {th }}, 1789$, the archivist Zidardia and Fray Diego Manuel Pucheta worked on a 98-page inventory of the provincial archive in two copies. One of these copies was given to the Provincial and his successors, the other was kept by the archivist. The very same day, both Fray Juan Antonio Ravelo, as the

\footnotetext{
${ }^{26}$ Catálogo del Archivo de la Provincia de Santa Cruz, p. 266. The Provincial looks for "un eficaz remedio a tanto daño (que no es de ahora solamente, pues se descubre que hasta la falta de los Libros difinitoriales del año de mil seiscientos dieciocho para atrás y ya se ve que su falta trae a la Provincia el desconsuelo de no saber las operaciones de aquellos primeros venerables Padres que componían este Difinitorio).”

${ }^{27}$ Catálogo del Archivo de la Provincia de Santa Cruz, p. 267.

${ }^{28}$ Irigoyen was meant to be experienced ,en todos los asuntos concernientes a las memorias perpetuas y Procuración General de Provincia.” Catálogo del Archivo de la Provincia de Santa Cruz, p. 267.

${ }^{29}$ There was only one exception when Irigoyen was obliged to participate, but only in a kind of spiritual gathering: "Y por último tenga para cumplir sus comisiones todos los auxilios, ordena y manda que ningún prelado le compela a la asistencia de acto alguno de comunidad, pues sólo deberá concurrir al de la oración mental cuando no esté legítimamente impedido.” Catálogo del Archivo de la Provincia de Santa Cruz, p. 267.
} 
secretary of the province council, and Zidardia, signed each paragraph of the inventory with their "rúbricas" when the whole archive was given to the latter's custody. ${ }^{30}$ The inventory was continued after 1789 . Below the "rúbricas" of several sections, we can find additional documents. So the inventory was augmented later on, at least up to 1803, the date of the most recent document. ${ }^{31}$ In some cases, who gave additional documents to the archivist was thoroughly noted, ${ }^{32}$ in other cases, the additions were more negligent. ${ }^{33}$

The whole archive is composed of 32 sections (in most cases "cajones," in some others "legajos") which are defined through a geographical subject or the institution of origin. The 20 initial "cajones" belong to the first definition: four of them refer to the Province of Santa Cruz as a whole, the following ones gather the documentation about the smaller administrative entities, 14 monasteries ("conventos") and two hospices ("hospicios"). Only the final section of the archive - about the missions - is again defined through the geographical or administrative subject (“Cajón de Doctrinas"). The six sections in between were chosen according to the provenance. The institutions of origin were the papal Curia in Rome ("Bulas Pontificias"), the Court in Madrid ("Cédulas Reales," 34 "Reales Provisiones") and the four influential authorities within the Franciscan Order in Lima and Madrid. ${ }^{35}$ With only a few exceptions, the documents are arranged in chronological order, starting with the oldest. The characteristics of each document -

\footnotetext{
30 Catálogo del Archivo de la Provincia de Santa Cruz, pp. 265-266: “Que por cuanto nuestro muy reverendo Padre Vicario Provincial, Fray Lucas Francisco Martel, Lector Jubilado del Número, doctor teólogo, Vice-comisario de los Santos Lugares de Jerusalen, ex-dos veces custodio, ex-Provincial, verbalmente me [al secretario Ravelo] ha ordenado ponga en testimonio fehaciente en este Libro inventario del Archivo de Provincia (que por duplicado y de noventa y ocho fojas cada uno, le ha presentado el Archivero de ella) el auto del venerable difinitorio de diecinueve de Mayo del año pasado de mil setecientos ochenta y ocho [...], y que inmediatamente entregue el Archivo a el enunciado Archivero [Zidardia], el tenor de dicho inventario, cerrando cada división de él con mi rúbrica y con la del Archivero.”

${ }^{31}$ Catálogo del Archivo de la Provincia de Santa Cruz, p. 269.

32 Catálogo del Archivo de la Provincia de Santa Cruz, p. 289.

${ }^{33}$ In the case of many posterior royal orders, the entry lacks a date. Catálogo del Archivo de la Provincia de Santa Cruz, p. 322.

34 "Cédulas Reales" with a clear geographical relation are categorized in later sections.

${ }^{35}$ Cajón de Patentes Superiores Comisarios del Perú, Legajo de Cartas de los Reverendísimos del Perú, Legajo de Patentes de los Ministros Generales de todo e Orden y sus Comisarios de Madrid.
} 
whether it is an original, a copy, or a draft, for instance - are scrupulously mentioned. ${ }^{36}$

Although in the prologue the loss of some of the oldest documents is lamented, the age of the documents is not valued per se. The juridical value of the archive is normally rather taken into account than the historical value. In a majority of the monasteries, a miscellaneous entity is described only as "old writings." Only documents specifically referring to the foundation of a monastery are listed separately. ${ }^{37}$ This idea of juridical insignificance becomes clear with the example of the village of Santa Rosa next to the Franciscan monastery in Carora. The documentation on this village is only roughly described as a "bundle" without any details, because the village did not exist any longer at that time. It had already been demolished on the Spanish king's orders. ${ }^{38}$ The historical value of the documents is rather neglected. A hint for an awakening of historical conscience in various provinces of the order may be a letter from General Minister Cayetano Laurindo. In 1741, he asked the Province of Santa Cruz for "material in Latin" for the successors of Luke Wadding. Between 1625 and 1654, Wadding had published the "Annales Minorum" in eight volumes, and for supplement volumes, more recent information was needed from the provinces. ${ }^{39}$

The inventory was intended as an authenticated overview of the archive's content, as is highlighted in the foreword and the decision of the council. But it was much more, because in its structure, it reflects the physical storage of the documents, in 25 big boxes ("cajones"), which were composed of loose documents, bundles ("legajos") or bound volumes. It was used as a finding aid for the archivist, not only by describing in detail the archive's content, but also by sorting things

\footnotetext{
36 These categories are for instance "tanto simple," "rescrito impreso," "borrón," “carta original," "rebaja simple” and "testimonio auténtico.” Catálogo del Archivo de la Provincia de Santa Cruz, pp. 276, 279, 287, 293, 296.

${ }^{37}$ Catálogo del Archivo de la Provincia de Santa Cruz, p. 282 (Convento de Santo Domingo), p. 289 (Convento de Santa Clara de Santo Domingo); p. 291 (Convento de Trujillo); p. 293 (Convento de Margarita); p. 293 "Primeramente razón de la fundación de dicho Convento y varias escrituras encuadernadas” (Convento de Coro); p. 294 (Convento de Maracaibo); p. 295 (Convento de Barquisimeto); p. 297 (Convento de Valencia); p. 299 (Convento de Cumaná); p. 300 (“Hospicio de la Trinidad”).The "escrituras antiguas" are only counted in some of these cases.

${ }^{38}$ Catálogo del Archivo de la Provincia de Santa Cruz, pp. 296-297: „It[em] un legajo de papeles relativos al Pueblo de Santa Rosa de Tequere de la jurisdicción de Carora, mandado demoler por el Rey nuestro señor.”

${ }^{39}$ Catálogo del Archivo de la Provincia de Santa Cruz, p. 332.
} 
out. Documents which were not categorized as relevant enough for a more detailed description were mentioned in more general terms. Especially the "Letters from the Reverendísimos del Perú" were registered in a more summarizing way, due to the fact that manifold subjects were treated in each document. ${ }^{40}$ The same observation is valid for the writings of the General Ministers, where "various orders" 41 or "some aspects about good governance" were transmitted in the same document. ${ }^{42}$ Zidardia probably did not read all the documents but only copied the synoptic annotations which the original addressee or a secretary had left on the folded letters. ${ }^{43}$

Another function of this detailed inventory can be found through the numerous references to Zidardia throughout the lists. Only then does it become clear that Zidardia was the reviser of all the Franciscan archives in the Province of Santa Cruz, not only of the provincial archive in Caracas. Zidardia's name is normally mentioned when he confirms the numbers of masses celebrated in memory of a deceased person in each convent. He could prove that in Caracas, Trujillo, and other monasteries numerous of these masses were paid, but not said. To compensate for this fraudulent activity, a restitution to the benefactors was discussed. ${ }^{44}$ He furthermore indicated an intentional loss of documents about these masses. Although the former owner of these documents was known, it was impossible to obtain them or to reconstruct their content. ${ }^{45}$ It is hard to decide whether the "loss" of masses was one of many motives to write this detailed inventory or

\footnotetext{
${ }^{40}$ For example Catálogo del Archivo de la Provincia de Santa Cruz, p. 325: "N. ${ }^{\circ}$ 1. Primeramente carte de N[uestro] R[everendo] P[adre] Fr[ay] Gabriel de Guilléstegui sobre varios puntos concernientes a la paz y unión de esta Provincia, fecha en 8 de Octubre 1660.”

${ }^{41}$ Catálogo del Archivo de la Provincia de Santa Cruz, p. 327: “3. - It[em] Otra [patente] de N[uestro] R[everendísi]mo P[adre] Fr[ay] Alonso de Prado, de diferentes órdenes, en 20 de Abril 1654."

${ }^{42}$ Catálogo del Archivo de la Provincia de Santa Cruz, p. 330: “55. - It[em] Otra [patente] del mismo [José Sanz] en que ordena diversos puntos para el buen gobierno de la Provincia, en 11 de Julio 1717”; p. 334: “112. - It[em] Otra [patente] del mismo [Manuel de la Vega] que contiene varios puntos de gobierno, en 9 de Noviembre 1772." The same is valid for the "Cartas de los Ministros Generales y sus Comisarios de Madrid”, for example p. 336: “5. - It[em] Otra [carta] de N[uestro] R[everendísi]mo P[adre] Fr[ay] Julián Chumillas sobre varios puntos, en Julio de 1691.”

43 Catálogo del Archivo de la Provincia de Santa Cruz, pp. 286, 298 ("varios asuntos”).

${ }^{44}$ Catálogo del Archivo de la Provincia de Santa Cruz, pp. 283-286.

${ }^{45}$ Catálogo del Archivo de la Provincia de Santa Cruz, p. 285.
} 
whether the detection of this malpractice within the Franciscan order was an unintended result of Zidardia's efforts.

\section{The Jesuit Archive in Buenos Aires - Order before Suppression?}

The case of the Jesuit Province of Paraguay is a good example for the dispersion and partial destruction of documents. ${ }^{46}$ After the suppression of the Society of Jesus in Spanish America in 1767, one part of the Jesuit documents was brought to Spain according to the orders of the king. But a significant portion was left in Asunción, Buenos Aires, and Córdoba de Tucumán and was only concentrated in state archives and private collections after the middle of the $19^{\text {th }}$ century. ${ }^{47}$ Today, we can find the Jesuit documents not only in Spain and Latin America, but also in Germany, the Czech Republic, and many other countries. ${ }^{48}$ Normally, the dispersion of the Jesuit documents in the years after the suppression is seen as a "catastrophe" for an apparently perfect order of complete series. Only with archival inventories preceding the suppression we can analyze whether such assumptions can be verified. ${ }^{49}$

${ }^{46}$ For an overview Franz Obermeier, "Jesuitische Bibliotheken und Archive im kolonialen La Plata-Raum. Fortleben, Zerstreuung und Zusammenführung”: Wolfenbütteler Notizen zur Buchgeschichte, 37 (2012), pp. 75-89; Carlos Leonhardt, Papeles de los antiguos Jesuítas de Buenos Aires y Chile, Buenos Aires: Imprenta de la Universidad, 1926.

${ }^{47}$ Francisco Mateos, “Introducción. Notas Históricas sobre el antiguamente llamado ‘Archivo de las temporalidades’ de Jesuitas”: Araceli Guglieri Navarro, Documentos de la Compañía de Jesús en el Archivo Histórico Nacional, Madrid: Editorial Razón y Fe, 1967, pp. V-LXXXII; Constancio Eguía Ruiz, "Dispersión total de los papeles jesuíticos en España”: Hispania, 11 (1951), pp. 679-702.

${ }^{48}$ Bernhard Duhr, "Zur Geschichte des Jesuitenordens aus Münchener Archiven und Bibliotheken”: Historisches Jahrbuch, 25 (1904), pp. 126-167; 28 (1907), pp. 61-83, 306-327; Simona Binková, "La antigua Provincia del Paraguay de la Compañía de Jesús en documentos y escritos coetáneos (Fondos de Bohemia y Moravia)": IberoAmericana Pragensia, 32 (1998), pp. 207-217; Raúl A. Molina, Misiones argentinas en los archivos europeos, Mexico City: Instituto Panamericano de Geografía e Historia, 1955.

49 Friedrich, "Archives as Networks"; idem, "Government and InformationManagement in Early Modern Europe. The Case of the Society of Jesus (1540-1773)”: Journal of Early Modern History, 12 (2009), pp. 1-25. Interestingly, there are only a few studies about Jesuit local archives. Besides the cases mentioned in Friedrich's studies, see Josef Franz Schütte, El "Archivo del Japón”. Vicisitudes del archivo jesuítico del extremo oriente y descripción del fondo existente en la Real Academia de 
The catalogue for the archive in the Jesuit College in Buenos Aires was written in $1761 .^{50}$ According to it, the archive was structured in 9 drawers ("gavetas"), which contained all in all 50 bundles ("legajos"). The most important fact is that there are practically no "pure" archival entities, neither in regard to provenance nor to subject. In many cases, there is only a very approximate description of the content, without any reference to specific documents. The first drawer has the best structured content, compared to the others. Most documents in the first two bundles are 79 papal bulls. None of these bear an exact date, but the name of the pope who issued it. In the first bundle, they are at least chronologically structured in the order of the pontificates, but in the second one, not even that is the case. That seems to be only a minor detail, but we will come back to this point later. There are several documents spread in both bundles which are obviously not of papal origin, among them three edicts of the Inquisition and a permission of a Royal Council. Others have no juridical value at all, for example an "Account of the solemn ceremonies during the beatification of Saint Regis" from an unspecified origin. ${ }^{51}$ In the following bundle, the papal documents are also predominant, but most of them are from a lower rank, for example from the Spanish nuncio, or they are specifically addressed to the Jesuits in Paraguay. Among them, we can for instance identify proofs for the relics which were adored in Paraguay. ${ }^{52}$ Besides, there is a shift for royal orders ("cédulas reales") which are only described with a few words. Neither the date of issue nor the name of the king was noted; only in three cases, Philip V is mentioned, and only in one case is the order identifiable beyond any doubt: in the case of the famous "Cedula Magna de Phelipe V." 53 These description practices are quite unusual. In administrative correspondence, the date of issue

la Historia de Madrid, Madrid: Academia de la Historia, 1964, pp. 29-45; Restrepo Zea, "La formación de la memoria".

50 Índice de los Papeles del Archivo [del Colegio de la Compañía de Jesús en Buenos Aires] Año de 1761.” Around 1800, this document was part of the collection of Saturnino de Segurola. Today it can be consulted in Buenos Aires, Museo Mitre, Armario B, Cajón 18, $\mathrm{N}^{\circ}$ de Orden 33, doc. 1.

51 Índice de los Papeles del Archivo, Gaveta 1.a Legajo 1.o; Gaveta 1.a Legajo 2.o.

52 Índice de los Papeles del Archivo, Gaveta 1.a Legajo 3.o; one example for the relics: "Testim[oni]o de las reliquias de los SS. [=santos] MM. [=mártires] Justo, Feliz, Victor y Maximo, q[ue] estan en este Col[egi]o [en Buenos Aires].”

53 Índice de los Papeles del Archivo, Gaveta 1.a Legajo 4.o; About this eminent and debated order see Magnus Mörner, "The Cedula Grande of 1743”: Jahrbuch für Geschichte von Staat, Wirtschaft und Gesellschaft Lateinamerikas, 4 (1967), pp. 489505. 
(or at least the reign on the responsible king) was the most important information to refer to a specific document, because the exhaustive lists of these numerous documents ("cedularios") were chronologically ordered.

The reason for the division between the first and the second "gaveta" is not very clear. There are no thematic needs. The line to the second one is probably drawn exclusively due to practical questions of storage, because the "gaveta" was not an imposed structure, but a physical entity. So the number of the "gaveta" was not only a rough thematic orientation, but also a location. The last bundles of the first "gaveta" finish with documents in their majority about internal orders and letters within the province concerning liturgical questions. ${ }^{54}$ The five bundles of the second "gaveta" are much more miscellaneous than in the first drawer. There are scarcely recognizable priorities like the communication with local Spanish authorities, questions of finance and trade, pamphlets, taxes and instructions, and powers of procurators. The content of the following drawer is also quite heterogeneous, with a certain emphasis on financial questions, including testaments in favor of the Society of Jesus. ${ }^{55}$ The last four drawers are described document by document, but there is no recognizable emphasis, neither in the content of the documents nor in the categories of documents. ${ }^{56}$ The inventory was conceived to be continued. There are several blank pages between the different "gaveta"-lists, and in fact, here and there are single additions written by another hand. ${ }^{57}$

An inventory of an archive is the result of various decisions and limitations. Serial sources like accounts, visitation reports, catalogues of the members of a province, annual letters etc. had to be written regularly due to internal rules. However, we never know which parts of them were actually written, and not each of them was preserved in an archive. In addition, probably not all of the preserved documents were listed in an inventory, and many of them not separately, but only in an utterly summarized form. From these ways of summarizing and sorting things out, we can deduce the value and the purpose of different genres of sources in the daily business of the Jesuit administration.

\footnotetext{
54 Índice de los Papeles del Archivo, Gaveta 1.a Legajo 5.o; Gaveta 1.a Legajo 6.o.

55 Índice de los Papeles del Archivo, Gaveta 3.a Legajo 1.o; Gaveta 3.a Legajo 2.o; Gaveta 3.a Legajo 3.o.

56 Índice de los Papeles del Archivo, Gaveta 6.a Legajo 1-6; Gaveta 7.a Legajo 1-7; Gaveta 8.a Legajo 1-8; Gaveta 9.a Legajo 1-8.

57 Índice de los Papeles del Archivo, pp. [25], [38], [56].
} 
The summarized description is a specific case in limbo: The documents are valuable enough to be preserved, but their content is not important enough to be registered document by document. One genre in this classification is composed of the edifying letters, collections of successful scenes of evangelization, baptisms of the indigenous inhabitants of the reductions, and martyrdom of the Jesuit missionaries. In their printed form, in the well-known collections of the "Lettres édifiantes," "Der Neue Welt-Bott," and "Cartas Edificantes," they make up an important and highly visible part of the (apologetic) media output of the Jesuits, but in the archive, they obtain only a peripheral status. They do not have any normative value, but as a testimony of evangelization they played a certain role in the missionary selfawareness. They circulated between the provinces and were read in the refectory. ${ }^{58}$

It is not that easy to recognize and define the rules of how documents were registered. The extent to which the documents were indexed did not depend on only one factor. Even crucial notarial contents were registered only in a very general form, for example the "documents on the lands of the College" in Buenos Aires and several maps and floor plans. ${ }^{59}$ Even the documents about the Jesuits' vows and about the benefactors were given only in a very general entry. ${ }^{60}$ One explanation might be that this documentation, as most of the cases, was kept as possible proof in legal disputes. The Jesuits' vows probably contain older lists which were not needed in daily administration.

Throughout the inventory, the specific form of the documents is noted, so there are remarks whether a document is a print or a handwritten duplicate or triplicate. In the case of three letters it is added that they were written personally by eminent individuals: by Diego Lainez, direct successor of Ignatius of Loyola as Superior General of the Society of Jesus, by the "Venerable" Father Juan de Romero, ${ }^{61}$ and

\footnotetext{
58 Índice de los Papeles del Archivo, Gaveta 5.a Legajo 1.o; Gaveta 5.a Legajo 2.o. About the source value of these edifying news-letters see Renate Dürr, "Der 'Neue Welt-Bott' als Markt der Informationen? Wissenstransfer als Moment jesuitischer Identitätsbildung“: Zeitschrift für Historische Forschung, 34 (2007), pp. 441-466; Markus Friedrich / Alexander Schunka (eds.), Reporting Christian Missions in the Eighteenth Century. Communication, Culture of Knowledge and Regular Publication in a Cross-Confessional Perspective, Wiesbaden: Harrassowitz, 2017.

59 Índice de los Papeles del Archivo, Gaveta 4.a: "En ella están las escrituras y Papeles de las Tierras del Colegio;” Gaveta 5.a Legajo 4.o: "Varios dibuxos y Plantas.”

60 Índice de los Papeles del Archivo, Gaveta 5.a Legajo 3.o: "Professiones y grados”; Gaveta 5.a Legajo 6.o: "Sufragios por varios Bienhechores."

61 Índice de los Papeles del Archivo, Gaveta 5.a Legajo 5.o.
} 
by Julian de Lizardi. The latter had been killed by the Chiriguanos in the Northwest of the Jesuit Province of Paraguay (Ingre Valley, current Bolivia) in 1735, that means 26 years before the inventory was made. ${ }^{62}$ These examples show that the archivist was aware of the extraordinary value and specific material character of the autographs. The documents were not listed among the other numerous letters, which were normally written by the secretary or by a copyist, but in a section that was dedicated to documents that could be used nearly as "relics" in the case of a later beatification or canonization, and to texts that were directly linked to them. In the case of the autographs by Diego Lainez and Juan de Romero, for example, the only documents in the same bundle are an "Account of the death of the Venerable Father Pedro Romero," one of the first martyrs of the Province of Paraguay, ${ }^{63}$ and the "Account of the Chiquito Missions," written by Lucas Cavallero. This father was also martyrized, in 1711 by the Puyzoca in the Province of Paraguay.

All in all, this inventory was not easy to use, due to the miscellaneous content of the bundles. The inventory of the archive is perhaps a mere description of the holdings, and when it was made, the order of the documents was not altered at all. This may explain why only the drawers and the bundles are enumerated, but not the documents. Even the person who was responsible for this inventory apparently understood that another tool was needed to facilitate its use. For this purpose, an alphabetical index of the "most important topics" was added. ${ }^{64}$ Unfortunately, many of the 63 headwords were as vague as the descriptions of the documents. Entries like "heterogeneous orders," "several drawings," and "multiple reports" are not really helpful. ${ }^{65}$

62 Índice de los Papeles del Archivo, Gaveta 5.a Legajo 7.o; Javier Baptista / Antonio Menacho, “Lizardi, Julián de”: Charles E. O’Neill / Joaquín María Domínguez (eds.): Diccionario histórico de la Compañía de Jesús. Biográfico-temático, Rome / Madrid: Institutum Historicum Societatis Iesu / Universidad Comillas, 2001, vol. 3, p. 2399.

63 Hugo Storni, “Mártires del Paraguay”: Charles E. O’Neill / Joaquín María Domínguez (eds.): Diccionario histórico de la Compañía de Jesús. Biográfico-temático, Rome / Madrid: Institutum Historicum Societatis Iesu / Universidad Comillas, 2001, vol. 3, pp. 2540-2541.

64 Índice de los Papeles del Archivo, p. [55]: “Indice de las materias principales, que se contienen en el Archibo, reducidas á Orden alphabetico, con remissiones al Indice precedente."

65 Índice de los Papeles del Archivo, p. [56] “Cedulas heterogeneas”; p. 58 “Dibujos varios", "Informes varios." 
Although this inventory from 1761 does not seem to be particularly sophisticated, an earlier attempt reveals that a certain progress had already been made. An undated inventory, supposedly written only a few years before, comprises only the first "gaveta." 66 The description of nearly every document considerably differs from the later inventory. From that we can deduce that they were made independently from each other. Three main differences show that there were no strict rules to compose an archive inventory. First of all, many of the descriptions in the earlier inventory are much more detailed, so it is easier to identify a document without consulting the original. Secondly, there seems to have been an attempt to give a certain structure at least to the first bundle of the first drawer: In this spot, the papal bulls were ordered according to the pontificates, and the pontificates for their part were ordered chronologically - but in the subsequent bundle, which also contains papal bulls, this attempt to give a certain logical coherence was abandoned. Thirdly, several subdivisions of a "legajo," smaller bundles ("atados"), were dissolved to allow a better description. In the earlier inventory, one of the bundles of the first drawer contained six "atados," whereas in the inventory from 1761 three of them had been dissolved and described document by document. The dissolved "atados" contained more recent orders and especially letters from the Generals. Outdated "legal customs" and seven annual letters from the early $18^{\text {th }}$ century were still kept in "atados." 67

\section{"An Index or Catalogue of the Matters to Be Cared For" - Interference between Archive and New Types of Documents}

So far we have seen that both of the archives that we have observed were thought of as a repository for general and local rules from Rome, Spain, and local authorities within and without the religious order. In both cases, there are special documents in the archives that try to systemize the amount of heterogeneous legislation: There are so-called "Abecedarios," that means alphabetical lists of the most important subjects with related quotations from letters and rules, cartularies, and other collections of rules and intern councils.

\footnotetext{
${ }^{66}$ Museo Mitre (Buenos Aires), Armario B, Cajón 18, $\mathrm{N}^{\circ}$ de Orden 33, doc. 2, without title (hereinafter: Índice primero).

67 Índice primero, pp. 9-10.
} 
But which relevance did these finding aids have? Were they composed to supplement, to facilitate, or to replace the consultation of the original documents in the archive? In the Franciscan and the Jesuit case, the status of these documents differs a lot. In the Franciscan order, these collections of local rules were supplemented step by step and replaced by printed handbooks for the laws in a Franciscan Province. ${ }^{68}$ In the Jesuit case, the question of the distribution, codification, and validity of local rules was highly debated. In the case of general rules, there was no doubt: The Constitutions as the words of Saint Ignatius and the accepted decrees of the General Congregations were regularly printed. ${ }^{69}$ Local rules might be seen as a part of the Jesuit accommodation method. However, an emphasis on these local solutions would have questioned the spirit of unity among the Jesuits. ${ }^{70}$ Therefore, local Jesuit rules were never printed. Nevertheless, there was a certain need for a local distribution and systematization of the relevant rules.

For the South American case, local debates about this systematization are well documented. Especially for the Paraguayan province, the members of the first Provincial Congregation demanded from the General in 1608 that all the local problems addressed to him

"with all the answers given by him to all the Colleges and Houses shall be sent by the Provincial to Rome, and after the examination of all of them our General may decide what is going to be kept, and he shall order, that this should be printed."71

There is an initial optimism behind this suggestion. With this printed book the Fathers from Paraguay sought to organize local legislation efficiently. Thus, the General should not be forced "to repeat what in

${ }^{68}$ As an example for Mexico: Constituciones y leyes municipales de esta Provincia del Santo Evangelio, México: Por la viuda de Calderón, 1667. For the broader context of Franciscan local legislation see Gómez Canedo, "Un capítulo"; Antonine Tibesar, "The Franciscan Province of the Holy Cross of Española, 1505-1559": The Americas, 13 (1957), pp. 377-397. About Franciscan written culture - which does not stand behind the Jesuit counterpart in the least - see Federico Palomo, "Written Empires. Franciscans, Texts, and the Making of Early Modern Iberian Empires": Culture \& History Digital Journal, 5: 2 (2016), pp. 1-8.

69 Augustus Coemans, Breves notitiae de instituto, historia, bibliographia societatis, Rome: Apud oeconomum generalem, 1930; Antonio de Aldama, "La Composición de las constituciones de la Compañía de Jesús”: Archivum Historicum Societatis Iesu, 42 (1973), pp. 201-245.

70 On the Jesuit spirit of unity see Michael Sievernich / Günter Switek (eds.), Ignatianisch. Eigenart und Methode der Gesellschaft Jesu, Freiburg im Breisgau: Herder, 1990.

${ }^{71}$ Archivum Romanum Societatis Iesu, Congregationes (hereinafter ARSI Congr.) 52, f. 183r. 
other cases already had been answered."72 The letters from the General were seen as an unchanging and generally admitted collection of rules, just in the same category as the Constitutions. The Jesuits from Paraguay even had the idea that in each group of provinces, which were united by the General's Assistant, the letters from the General should be collected and transmitted to the other Assistances. ${ }^{73}$

However, after the initial belief in bureaucracy, there were various attempts to sort out irrelevant rules to limit the overwhelming amount of legal documents that was received in Paraguay over the years. But the attitude of the Generals towards the suggestions from Paraguay was not consistent at all. In 1626, General Claudio Acquaviva accepted the abolishment of the local rules that had become useless, ${ }^{74}$ but in 1717, General Tirso González denied it. ${ }^{75}$ In 1756, the Provincial Congregation in Paraguay asked not only for the reduction of the rules, but the Jesuits also demanded

"that the so-called customs and the laws of this Province should be reorganized, so that some of them, which are out of use, will be deleted, and others, which refer to certain individuals or offices, will be confirmed. And only those that are relevant for all should be read during the meals. All the others should be owned only by the respective addressee."76

In this final case, the General neither accepted nor denied the proposal. He wanted the Jesuits from Paraguay to name the allegedly unnecessary rules - but the Fathers apparently never mentioned any, so this suggestion did not have any effect. ${ }^{77}$ Another facet of this juridical meta-discourse was the attempt to introduce a time limit in advance for the validity of a rule. In 1637, a small group of Paraguayan missionaries wanted the General to order that the rules for the missions should be valid only for a short time period, "because circumstances change quickly there.” ${ }^{\prime 78}$ General Mutio Vitelleschi refused any general limitation of rules. Instead, he saw the Provincial as responsible for modifying local rules. ${ }^{79}$ This discussion was not unique at all. Already in 1579, the Jesuits in New Spain tried to make a difference between strict "rules" ("reglas," “órdenes”) and more flexible "guidelines”

\footnotetext{
72 ARSI Congr. 55, f. 173v.

${ }^{73}$ ARSI Congr. 75, f. 189r.

74 ARSI Congr. 61, f. 278v.

${ }^{75}$ ARSI Congr. 88, f. 341r, 344.

${ }^{76}$ ARSI Congr. 92, f. 155r.

77 ARSI Congr. 92, f. 155v.

${ }^{78}$ ARSI Congr. 67, f. 225r.

${ }^{79}$ ARSI Congr. 67, f. 227r.
} 
(“directión," "ayuda del govierno"), ${ }^{80}$ and in other provinces, similar questions may have emerged. But this interprovincial comparison has not been very advanced in the case of historiography on the Jesuits until now. ${ }^{81}$

Thus, we can locate the role of Jesuit local archives in the tense atmosphere of two discussions: firstly about the solution of legal problems with casuistic, local rules on the one hand or general ones for the whole Society of Jesus on the other, ${ }^{82}$ and secondly about the status of local rules for the Jesuit Institute. Whereas in the case of the Franciscans local rules were fully accepted and even spread in print, in the Jesuit case their rank was not that clear. In all of the 19 General Congregations of the Jesuits before their suppression in 1773, only once the status of local rules was discussed. In 1608, the $6^{\text {th }}$ General Congregation decided that "an index or catalogue of the matters to be cared for by superiors, both provincial and local" should be made in each province. But this catalogue was not meant as a strict legal book, but rather as "an aid to memory" for the superiors to be read regularly. ${ }^{83}$

80 Felix Zubillaga (ed.), Monumenta Mexicana, Rome: Institutum Historicum Societatis Iesu, 1956, vol. 1, p. 433.

${ }^{81}$ Some of the scarce examples of interprovincial comparison can be found in Tobias Winnerling, Vernunft und Imperium. Die Societas Jesu in Indien und Japan, 1542-1574, Göttingen: Vandenhoeck \& Ruprecht, 2014; Belén Navajas Josa, Aculturación y rebeliones en las fronteras americanas. Las misiones jesuitas en la Pimería y el Paraguay, Pozuelo de Alarcón: Universidad Francisco de Vitoria, 2011; Luke Clossey, Salvation and Globalization in the Early Jesuit Missions, Cambridge: Cambridge University Press, 2010.

${ }^{82}$ Martín M. Morales, Los comienzos de las Reducciones de la Provincia del Paraguay en relación con el Derecho Indiano y el Instituto de la Compañía de Jesús. Evolución y conflictos, Rome: 1995 (Diss.), pp. 69-71.

83 John W. Padberg / Martin D. O’Keefe / John L. McCarthy (eds.), For Matters of Greater Moment. The First Thirty Jesuit General Congregations. A Brief History and a Translation of the Decrees, St. Louis: Institute of Jesuit Sources, 1994, General Congregation 6, Decree 36, pp. 239-240: “1. To make it easier to know what matters superiors ought to be aware of, so that they can put them into practice, it was judged proper to develop an index or catalogue of the matters to be cared for by superiors, both provincial and local, drawn up in summary form, as an aid to memory. This sort of index is to be collected from rules, ordinations, and instructions.

2. It would aid to recall this information if superiors, together with their consultors, would on the occasion of the usual consultation also read through something from the rules, ordinations, instructions, and other books of that sort every eighth or fifteenth day, in accord with the instruction for visitors.

Each month the memorial of items to be observed should be read in the consultation that the Provincial or visitor left behind. The reason for this is to prevent it from fading from memory, and also to allow the consultors to remind the Provincial at appropriate times how it is being observed. Therefore, a copy of this kind of memorial is to be 


\section{Conclusion}

Archival inventories are a key to understanding forms of knowledge during colonialism and evangelization. They reflect how knowledge was structured, exploited, indexed, and sorted out. The Franciscan archive in Caracas and the Jesuit archive in Buenos Aires are comparable in importance, rank, institutional frame, and size. Their structure reveals that direct information supply is only a very idealized function of an archive. Neither the level of document order nor the many gaps justify the pre-empirical picture of these archives. Both analyzed archives and several other monastic ones from Latin America ${ }^{84}$ were revealed to work as information knots of both European and local knowledge. European norms are usually structured according to institutional and generic criteria (papal bulls, royal orders), while local information is organized in geographic entities. In many cases, the local documentation was not communicated to European authorities, but kept on a provincial level. This points to the assumption that in this case "local" knowledge is not the same as "colonial" knowledge. ${ }^{85}$ The only opportunity in which local knowledge was requested by European authorities was for the preparation of chronicles. But compared to the juridical functions of an archive, the historiographical purpose is clearly inferior.

In the Franciscan and the Jesuit cases, the archive is relevant for current legislation. This is not very surprising, as it is one of the core functions of archives in general. However, a closer look leads to more astonishing results. In the Jesuit case, the archive is a base for digests and excerpts of rules which were to be read during the meals. Therefore, the archive is a kind of reminder for all the members of a community within the Society of Jesus. But in the Franciscan case, the archivist's helper is seen as the person responsible for checking the observance of rules without pointing to a kind of collective memory. The comparative analysis of local Latin American archives is still in its early stages. It will be indispensable to compare the first results

issued to the admonitor and to the consultors, provided that there is nothing at it that refers to individual persons."

${ }^{84}$ Restrepo Zea, "La formación de la memoria".

${ }^{85}$ Brendecke, Imperium und Empirie, p. 386, note 37; Jürgen Osterhammel, Die Verwandlung der Welt. Eine Geschichte des 19. Jahrhunderts, Munich: Beck, 2009, pp. 1147-1148; Kapil Raj, Relocating Modern Science. Circulation and the Construction of Scientific Knowledge in South Asia and Europe, Seventeenth to Nineteenth Centuries, New Delhi: Permanent Black, 2006, p. 8-9. 
presented here with colonial inventories of archives of other orders and in other regions, including the local repositories of Spanish authorities. Only that way can we gain a better understanding of institutional characteristics and the gradual development of archival habits and structures.

Jahrbuch für Geschichte Lateinamerikas | Anuario de Historia de América Latina 